\title{
Genetic Relationships of Some Fastidious Xylem-Limited Bacteria $†$
}

\author{
SONDRA M. KAMPER, ${ }^{1}$ W. J. FRENCH,${ }^{2 *}$ AND S. R. DEKLOET ${ }^{3}$ \\ Department of Animal Science, University of Florida, Gainesville, Florida 32611 ${ }^{1}$; Agricultural Research and Education \\ Center, University of Florida, Monticello, Florida 32344²; and Department of Biological Sciences, Florida State \\ University, Tallahassee, Florida $32306^{3}$
}

\begin{abstract}
Fastidious, gram-negative xylem-limited bacteria were examined for genetic relatedness to each other and to members of the major phytopathogen-containing genera of gram-negative bacteria. All of the xylem-limited bacterial strains studied had deoxyribonucleic acid base compositions of approximately $50.5 \mathrm{~mol} \%$ guanine plus cytosine and genome molecular weights of $1.4 \times 10^{9} \pm 0.2 \times 10^{9}$. The results of our deoxyribonucleic acid-deoxyribonucleic acid hybridization experiments suggested that these strains are all related at the species level, but supported distinction at the varietal level, and possibly at the subspecies level between the bacteria causing Pierce's disease of grapevine and the bacteria causing phony disease of peach, plum leaf scald, and periwinkle wilt. No relatedness was detected between the xylem-limited bacteria and Erwinia chrysanthemi, Pseudomonas syringae pv. syringae, Xanthomonas campestris pv. campestris, or Agrobacterium tumefaciens.
\end{abstract}

The significance of the recently discovered fastidious gram-negative xylem-limited bacteria (XLB) in plant diseases has become increasingly evident $(8,15)$. XLB, also referred to as rickettsia-like bacteria, have been isolated from diseased plants, insect vectors, and apparently healthy reservoir plants $(8,15,26)$, indicating a complexity of XLB-host-vector interactions. Studies on etiology $(14,15$, 19), culture requirements $(6,8,25)$, serology $(7,12,20,22$, $26)$, and certain biochemical characteristics $(15,24)$ have indicated that the XLB are not related to the major phytopathogen-containing genera of gram-negative bacteria and can be subdivided into at least two closely related subgroups of unknown taxonomic distinction or affiliation.

In this study, the relatedness of several XLB to each other and to other gram-negative phytopathogens was examined and defined by the following three criteria: deoxyribonucleic acid (DNA) base composition, genome molecular weight, and DNA homology.

(The results were taken from a thesis presented by S.M.K. to Florida State University, Tallahassee.)

\section{MATERIALS AND METHODS}

Bacterial strains and culture conditions. Two strains of the plum leaf scald bacterium, strains PLSB-40 and PLSB-53, and one strain of the phony peach disease bacterium, strain PPDB-2.1, were isolated by W. J. French at Monticello, Fla. (strains PLSB-40 and PPDB-2.1) or Cascata, Rio Grande do Sul, Brazil (strain PLSB-53). One strain of the Pierce's disease bacterium, strain PDB-1, was provided by N. W. Schaad, University of Idaho, Moscow, and one strain of periwinkle wilt bacterium, strain PWB-1, was provided by M. J. Davis, University of Florida, Ft. Lauderdale. Stationary cultures of strains PLSB-40, PLSB-53, PPDB-2.1, and PWB-1 in PW broth (8) and shaker cultures of strain PDB-1 in PD2 broth (10) were grown at $28^{\circ} \mathrm{C}$ for 5 to 7 days. Erwinia chrysanthemi A-17, Xanthomonas campestris B-24, Pseudomonas syringae C-7, and Agrobacterium tumefaciens 84G-102 were provided by N. W. Schaad, Escherichia coli K-12 C600 was provided by H. J. Taylor, Florida State

\footnotetext{
* Corresponding author.

$\dagger$ Florida Agricultural Experiment Station Journal Series No. 5825 .
}

University, Tallahassee; these strains were grown for 1 to 2 days at $27^{\circ} \mathrm{C}$ in nutrient broth (Difco Laboratories, Detroit, Mich.) supplemented with $0.1 \%$ yeast extract (Difco) and $0.25 \%$ glucose on a shaker. Haemophilus influenzae Rd cells grown in brain heart infusion broth (Difco) supplemented with $10 \mu \mathrm{g}$ of hemin chloride per $\mathrm{ml}$ and $10 \mu \mathrm{g}$ of nicotinamide adenine dinucleotide per $\mathrm{ml}$ were a gift from J. H. Stuy.

Extraction and purification of DNA. Cells were harvested by centrifugation, washed twice with $1 \times$ standard saline citrate $(1 \times \mathrm{SSC} ; 0.15 \mathrm{M} \mathrm{NaCl}$ plus $0.015 \mathrm{M}$ trisodium citrate, $\mathrm{pH} 7$ ) and suspended in $0.25 \mathrm{M}$ sucrose $-2 \mathrm{mM} \mathrm{MgCl}$. The cells were lysed on ice in a solution containing $4.3 \mu \mathrm{g}$ of lysozyme (grade I; Sigma Chemical Co., St. Louis, Mo.) per $\mathrm{ml}$ for $5 \mathrm{~min}$ and then made $0.05 \mathrm{M}$ in ethylenediaminetetraacetate, and $1.1 \mathrm{ml}$ of lysis buffer $\{0.5 \%$ Sarcosyl, $6.2 \mathrm{mM}$ ethylenediaminetetraacetate, $50 \mathrm{mM}$ Tris [tris(hydroxymethyl)aminomethane]-hydrochloride, $\mathrm{pH} 8$ \} per $\mathrm{ml}$ of cells in lysozyme-ethylenediaminetetraacetate was added. After incubation on ice for $30 \mathrm{~min}$, the lysate was deproteinized with $1 \mathrm{mg}$ of protease (type XIV; Sigma) per $\mathrm{ml}$ at $37^{\circ} \mathrm{C}$ for $24 \mathrm{~h}$. DNA was then extracted and purified by the method of Marmur (17), using a mixture containing equal parts of phenol (pH 8) and chloroform-isoamyl alcohol (24:1) for the solvent extraction steps. Final purification was accomplished by equilibrium centrifugation on $\mathrm{CsCl}(1.6 \mathrm{~g} / \mathrm{ml})$ density gradients at $37,000 \mathrm{rpm}$ for $60 \mathrm{~h}$ in model A-321 rotor and a model B- 60 preparative ultracentrifuge (International Equipment Co., Needham Heights, Mass.). DNA was dialyzed into $2 \times \mathrm{SSC}$ and stored at $-20^{\circ} \mathrm{C}$. DNA concentration was estimated from absorbance at $260 \mathrm{~nm}\left(\mathrm{~A}_{260}\right)$, as determined with a Carey model 219 thermoprogrammable spectrophotometer (Varian Associates, Inc., Instrument Group, Palo Alto, Calif.). Purity was determined by high-pressure liquid chromatography base analysis (absence of uracil) and calculation of ratios of $A_{260}$ to $A_{280}$ (1.90 \pm 0.02 for all samples used).

Shearing. DNA $(200 \mu \mathrm{g} / \mathrm{ml})$ in $2 \times$ SSC was sheared by forcing it through a 26-gauge, 0.375 -inch $(0.95-\mathrm{cm})$ needle attached to a $1-\mathrm{ml}$ plastic syringe three times. This generated a large range of fragment sizes, with an average molecular weight of approximately $10^{7}$, as determined by agarose gel electrophoresis (Kamper, M. S. thesis, Florida State University, Tallahassee, 1984).

Preparation of $\left[{ }^{3} \mathbf{H}\right]$ DNA. ${ }^{3} \mathrm{H}$-labeled deoxycytidine tri- 
phosphate and ${ }^{3} \mathrm{H}$-labeled deoxyadenine triphosphate (New England Nuclear Corp., Boston, Mass.) were incorporated into DNA by nick translation (23), using a nick translation kit (type $8160 \mathrm{SB}$; Bethesda Research Laboratories, Inc., Gaithersburg, Md.) modified as follows to increase label incorporation: (i) the reaction buffer was modified to contain $0.4 \mathrm{mM}$ unlabeled deoxyguanidine triphosphate and $0.4 \mathrm{mM}$ unlabeled deoxythymidine triphosphate; (ii) $10 \mu \mathrm{Ci}(300$ pmol) of ${ }^{3} \mathrm{H}$-labeled deoxycytidine triphosphate and $10 \mu \mathrm{Ci}$ (300 pmol) of ${ }^{3} \mathrm{H}$-labeled deoxyadenine triphosphate were used per $0.4 \mu \mathrm{g}$ of DNA labeled; and (iii) nick translation was carried out for $3 \mathrm{~h}$ at $14^{\circ} \mathrm{C}$. The labeled DNA was fractionated on a Sephadex G-50-80 (Sigma) column ( 0.3 by $21 \mathrm{~cm})$ in $0.5 \times \mathrm{SSC}$, extracted with $90 \%$ phenol $(\mathrm{pH} 8)$, dialyzed against $0.5 \times \mathrm{SSC}$, and adjusted to a concentration of $0.8 \mu \mathrm{g} / \mathrm{ml}$ (assuming no loss of DNA during the procedure). The specific activity of the final product was $1.4 \times 10^{7}$ $\mathrm{dpm} / \mu \mathrm{g}$.

Determination of DNA base composition. The guanine-pluscytosine $(\mathrm{G}+\mathrm{C})$ contents of DNAs were determined by the methods of Marmur and Doty (18) and Felsenfeld (11). G+C contents of samples denatured in $0.5 \times \mathrm{SSC}$ were calculated from the temperatures at which one-half of the DNA was denatured $\left(T_{m}\right)$ by the method of Gillis et al. (13). G+C contents of samples denatured in $1 \times$ SSC were calculated from the following equation: $\mathrm{G}+\mathrm{C}$ content $=\left(T_{m}-\right.$ 65.2)/0.52. This equation better represented the control data obtained in this study. When thermal denaturation was complete, $A_{250}, A_{260}, A_{270}$, and $A_{280}$ were measured and analyzed for $\mathrm{G}+\mathrm{C}$ contents by the method of Felsenfeld for denatured spectra (11).

Determination of genome molecular weights. Genome molecular weights were determined essentially by the initial renaturation rate method of Gillis et al. (13). Samples thermally denatured in $0.5 \times \mathrm{SSC}$ for base composition determinations as described above were made $2 \times$ SSC by injecting $20 \times$ SSC through a silicone seal plug in the cuvette lid. Renaturation reactions were performed with large syringe-sheared fragments in $1 \times \mathrm{SSC}$ in order to obtain linear initial renaturation with the small genomes of the XLB at the chosen DNA concentration (approximately $80 \mu \mathrm{g} / \mathrm{ml}$ ). The apparent optical renaturation rates $(k)$ obtained for control samples, Escherichia coli and $\boldsymbol{H}$. influenzae were approximately $49 \%$ as large as those obtained by Gillis et al. (13). Thus, genome molecular weight $(M)$ was related to $k$ and $\mathrm{G}+\mathrm{C}$ content under our conditions by the following equation: $M \times 10^{-7}=[98.37-(0.91 \times \mathrm{G}+\mathrm{C}$ content $)] /(2.05 \times k)$. ( $k=v / c^{2}$, where $v$ is the initial rate of reaction and $c$ is the concentration expressed in $\mathrm{mM}$ nucleotide pairs.)

DNA-DNA hybridization. The method which we used for DNA-DNA hybridization was the Kamper modification of the initial renaturation rate method of De Ley et al. (10). The initial rate of reaction $(v)$ was determined by an $S 1$ nuclease assay of hybrid double-stranded DNA formation between single strands of $\left[{ }^{3} \mathrm{H}\right]$ DNA and unlabeled DNA. Samples of freshly denatured sheared DNA fragments $(25 \mu \mathrm{l}$ each) containing approximately $80 \mu \mathrm{g}$ of unlabeled DNA per ml and $16 \mathrm{ng}$ of $\left[{ }^{3} \mathrm{H}\right] \mathrm{DNA}$ per $\mathrm{ml}$ were hybridized in $2 \times \mathrm{SSC}$ for $4 \mathrm{~h}$ at the optimal renaturation temperature of the labeled sample.

The fraction of DNA base sequences in the labeled genome (genome $A$ ) that were homologous to sequences in the unlabeled genome (genome $B$ ) was determined by comparing the initial rates of hybrid formation in heterologous and homologous reactions. The following equation was adapted for use in this comparison: $M_{A} / M_{B}=k_{B} / k_{A}=$
$\left(v_{B} / v_{A}\right) \times\left(c_{A} / c_{B}\right)^{2}$. This equation is essentially the one developed by Gillis et al. (13) for genome molecular weight determinations. Concentration $(c)$ was expressed as millimoles of nucleotide pairs per liter in the hybridization mixture. The renaturation-hybridization rate $(v)$, expressed as counts per minute per minute, was obtained by dividing the counts per minute for hybridized DNA by the time of the reaction. In practice, reaction conditions under which renaturation did not proceed at a linear rate could be used as long as the ratio of $k_{B}$ to $k_{A}$ for the homologous hybridization reactions (i.e., strand renaturations) of genomes $A$ and $B$ was the same as the ratio obtained under conditions of linear renaturation. For instance, XLB and $\boldsymbol{H}$. influenzae DNAs did not renature linearly under the conditions of buffer and DNA concentration used for the hybridization reactions, and the DNAs of the other bacteria used renatured linearly for only about $30 \mathrm{~min}$ of the 4-h renaturation period. However, the ratio of $k_{B}$ to $k_{A}$ obtained in this way for the homologous hybridization reactions of strain PLSB-40 (genome $A$ ) and Escherichia coli (genome $B$ ) was virtually identical to the value obtained by optical determination of renaturation rates for the same samples in the study of genome molecular weights under conditions of linear initial renaturation. This was true whether hybridization was for 1 or $4 \mathrm{~h}$ with these samples. Therefore, in order to maximize the number of counts per minute assayed for each hybridization reaction, hybrization to labeled Escherichia coli or strain PLSB-40 DNA was carried out for $4 \mathrm{~h}$ in this study. In this case $v$ was actually an average rate. To determine the extent of DNA base sequence homology of two genomes, Kamper employed the above-mentioned formula to determine $M_{A}{ }^{\prime} / M_{A}$, a ratio of the "apparent" molecular weight, $M_{A}{ }^{\prime}$, of the labeled genome, $A$, obtained in a heterologous hybridization reaction (labeled genome $A$ and unlabeled genome $B$ ) and the true molecular weight, $M_{A}$, of genome $A$ obtained in a homologous reaction (labeled genome $A$ plus unlabeled genome $A$ ). The resulting ratio of $M_{A}^{\prime}$ to $M_{A}$ is a function of the base sequence homology between the two genomes involved. If the genomes are identical, the ratio of $M_{A}{ }^{\prime}$ to $M_{A}$ is 1 , and the level of homology is $100 \%$. If the level of homology is less than $100 \%$, the ratio of $M_{A}{ }^{\prime}$ to $M_{A}$ is more than 1 , and the labeled genome appears to be larger in the heterologous reaction as a result of a lower rate of base pairing. Each apparent doubling of the molecular weight of the labeled genome by heterologous hybridization corresponds to reduction by one-half in the DNA base sequence homology of the two genomes. The level of base sequence homology determined in this way is a direct measure of the fraction of labeled DNA involved in base pairing. Data $(k)$ obtained by this method varied by no more than $\pm 10 \%$ in reactions between samples having $\geq 75 \%$ homology.

S1 nuclease assay. The S1 nuclease method used was essentially the method described by Crosa et al. (5), with modification of the reaction buffer to permit digestion in SSC. An equal volume of a freshly made $S 1$ nuclease mixture was added and mixed well with a partially hybridized DNA sample in $2 \times$ SSC on ice. Digestion was allowed to proceed for $1 \mathrm{~h}$ at room temperature $\left(25^{\circ} \mathrm{C}\right)$. The $\mathrm{S} 1$ nuclease mixture was prepared within a few minutes of use by adding $0.25 \mu \mathrm{l}$ of S1 nuclease (catalog no. N5255; Sigma) and $5 \mu$ of freshly denatured syringe-sheared calf thymus DNA $(800 \mu \mathrm{g} / \mathrm{ml}$ in water) to $195 \mu \mathrm{l}$ of $0.067 \% \mathrm{HCl}-40 \mathrm{mM}$ $\mathrm{ZnSO}_{4}$. After digestion, the samples were put on ice and made $20 \mathrm{mM}$ in ethylenediaminetetraacetate; they were then spotted onto nitrocellulose filter papers and air dried. The 
TABLE 1. DNA characterization: base compositions and molecular weights of the strains tested

\begin{tabular}{|c|c|c|c|c|}
\hline \multirow[b]{2}{*}{ Bacterial strain } & \multicolumn{2}{|c|}{$\mathrm{G}+\mathrm{C}$ content $(\mathrm{mol} \%)$} & \multirow[b]{2}{*}{$\begin{array}{l}\text { Mol wt } \\
\left(\times 10^{y}\right)^{c}\end{array}$} & \multirow[b]{2}{*}{$\begin{array}{l}\% \text { Homology to } \\
\text { strain PLSB-40 }\end{array}$} \\
\hline & $\begin{array}{l}\text { Method } \\
\text { Marmur of } \\
\text { and Doty }\end{array}$ & $\begin{array}{l}\text { Method of } \\
\text { Felsenfeld }\end{array}$ & & \\
\hline PLSB-40 & 50.8 & 51.7 & 1.60 & 100 \\
\hline PLSB-53 & 50.0 & 50.5 & 1.27 & 104 \\
\hline PPDB-2.1 & 50.2 & 50.9 & 1.51 & 85 \\
\hline PWB-1 & 51.0 & 50.5 & & 97 \\
\hline PDB-1 (preparation 1) ${ }^{d}$ & 50.6 & 49.5 & 1.35 & 75 \\
\hline PDB-1 (preparation 2) ${ }^{d}$ & 50.7 & 49.6 & 1.34 & 74 \\
\hline Escherichia coli $\mathrm{K}-12 \mathrm{C} 600$ & 50.7 & 49.8 & $2.60 \pm 0.28$ & $<5$ \\
\hline Erwinia chrysanthemi A-17 & 54.8 & 56.4 & & $<5$ \\
\hline$P$. syringae $\mathrm{C}-7$ & 58.9 & 58.6 & $2.88 \pm 0.55$ & $<5$ \\
\hline A. tumefaciens $84 \mathrm{G}-102$ & 58.0 & 60.8 & $3.65 \pm 0.62$ & $<5$ \\
\hline$X$. campestris $\mathrm{B}-24$ & 67.0 & 65.1 & 2.20 & $<5$ \\
\hline H. influenzae $\mathrm{Rd}$ & 38.3 & 36.5 & $1.60 \pm 0.13$ & $<5$ \\
\hline
\end{tabular}

${ }^{a}$ See reference 18 . Values are averages of $0.5 \times \mathrm{SSC}$ and $1 \mathrm{xSSC}$ data, which varied by no more than \pm 0.8 mol\% $\mathrm{G}+\mathrm{C}$. One determination was made in each buffer for XLB strains; two or more determinations were made in each buffer for the other bacteria (except $H$. influenzae and $X$. campestris, which were measured only in $0.5 \times \mathrm{SSC}$ ).

${ }^{b}$ See reference 11 . One determination was made for each XLB strain; for the other bacteria, values are averages of two or more determinations. Sample variation was $\leq \pm 0.5 \mathrm{~mol} \%$, except for $A$. tumefaciens, which had a variation of $\pm 1.9 \mathrm{~mol} \%$.

' Two or more determinations were made for Escherichia coli $\mathrm{K}-12$ C600, P. syringae C-7, A. tumefaciens $84 \mathrm{G}-102$, and $H$. influenzae Rd: for all other strains one determination was made.

${ }^{d}$ Preparations 1 and 2 were separate DNA preparations of strain PDB-1.

filters were washed four times with ice-cold $5 \%$ trichloroacetic acid $-10 \mathrm{mM}$ sodium pyrophosphate and three times with ice-cold $95 \%$ ethanol, air dried, and counted in PCS scintillator fluid (Amersham Corp., Arlington Heights, Ill.) on a model LS 1800 liquid scintillation counter (Beckman Instruments, Inc., Fullerton, Calif.). Different batches of S1 nuclease received from Sigma exhibited different levels of nuclease activity on nondenatured $\left[{ }^{3} \mathrm{H}\right] \mathrm{DNA}$. This activity was measured for each batch, and data were corrected accordingly.

\section{RESULTS}

Base compositions of DNAs. The $\mathrm{G}+\mathrm{C}$ contents of the DNAs of the XLB strains (Table 1) averaged $50.6 \pm 0.5$ mol\% when the DNAs were assayed by the method of Marmur and Doty (18) and $50.5 \pm 0.6 \mathrm{~mol} \%$ when the DNAs were assayed by the method of Felsenfeld (11). These results are somewhat lower than the values of 52.0 to $53.1 \mathrm{~mol} \%$ $\mathrm{G}+\mathrm{C}$ previously reported for the XLB by Davis et al. (8) and Wells and Raju (24). The $G+C$ contents of all of the non-XLB strains studied (Table 1) agreed well with previously published values (21).

Genome molecular weight. The molecular weights of the genomes of the XLB strains averaged $1.4 \times 10^{9} \pm 0.2 \times 10^{9}$ (Table 1). The molecular weights of Escherichia coli, $H$. influenzae, and $A$. tumefaciens DNAs (Table 1) agreed well with previously published values $(9,13)$. The limited scope of this aspect of our investigation, coupled with the rather poor reproducibility obtained for control samples (results varied by as much as $\pm 19 \%$ within a single strain), prevented accurate comparisons among the XLB strains since the variation observed among these strains was only $\pm 14 \%$.

DNA homology. The levels of homology between various XLB strains and strain PLSB-40 ranged from 74 to $104 \%$ (Table 1). The levels of DNA homology between strain PLSB-40 and all non-XLB strains were less than 5\% (i.e., below the limits of detection by the method used).

Escherichia coli was found to be $11 \%$ homologous to Erwinia chrysanthemi and $35 \%$ homologous to Salmonella typhimurium by our method. These results compare well to those obtained by other workers $(2,3,5,10)$, thus confirming the comparability of our method to the methods of other researchers.

\section{DISCUSSION}

DNA base composition and genome molecular weight. The DNA $G+C$ contents and genome molecular weights of the XLB strains were indistinguishable in this study. The XLB are probably not related to organisms whose $\mathrm{G}+\mathrm{C}$ contents are outside the range of 45 to $56 \mathrm{~mol} \%$, such as Haemophilus species and the animal rickettsiae, or whose genome molecular weights are outside the range of $1 \times 10^{9}$ to $2 \times 10^{9}$, such as species of Erwinia, Pseudomonas, Xanthomonas, and Agrobacterium.

DNA homology. The XLB are not related at the species level and probably are not related at the genus level $(1,4,16)$ to any of the other bacterial species with which they were compared in this study. The high levels of DNA homology (80 to $100 \%$ ) of strains PPDB-2.1, PWB-1, and PLSB-53 to strain PLSB-40 indicate that genome molecular weight and differences in the linear arrangement of cistrons are probably the major variations that were measured among these strains (16). Subdividing this group would have to be on the basis of distinguishable phenotypic characteristics (16), such as pathogenicity (pathovars) or serological differences (serovars). The level of homology (approximately 75\%) observed between strains PDB-1 and PLSB-40, in combination with known phenotypic differences between these strains, is sufficient to support distinguishing these organisms at the varietal (genovariety) level and possibly the subspecies (genosubspecies) level (16), but not at the species level $(1,4$, 16).

Future investigations of possible taxonomic affiliations of the XLB to other groups of bacteria should be confined to those organisms whose base contents and genome molecular weights conform to the limits suggested above. Initial comparisons with such candidates by less specific criteria, such as ribosomal ribonucleic acid homology, might be a more 
efficient means of eliminating taxonomically distant groups from DNA level comparisons.

\section{ACKNOWLEDGMENTS}

This research was supported in part by competitive grant 5901-0-410-9-0295-0 from the Department of Agriculture Science and Education Administration to W.J.F. and N. W. Schaad.

We thank R. Reeves for his gift of $S$. typhimurium DNA, M. Grossman for high-pressure liquid chromatography base analyses, and R. J. Kamper for writing the computer program used for the analysis of data by the Felsenfeld method.

\section{LITERATURE CITED}

1. Brenner, D. J. 1973. Deoxyribonucleic acid reassociation in the taxonomy of enteric bacteria. Int. J. Syst. Bacteriol. 23:298-307.

2. Brenner, D. J., G. R. Fanning, K. E. Johnson, R. V. Citarella, and S. Falkow. 1969. Polynucleotide sequence relationships among members of the Enterobacteriaceae. J. Bacteriol. 98: $637-650$.

3. Brenner, D. J., G. R. Fanning, and A. C. Steigerwalt. 1977. Deoxyribonucleic acid relatedness among erwiniae and other enterobacteria. II. Cornstalk rot bacterium and Pectobacterium chrysanthemi. Int. J. Syst. Bacteriol. 27:211-221.

4. Colwell, R. R., R. Johnson, L. Wan, T. E. Lovelace, and D. J. Brenner. 1974. Taxonomy and deoxyribonucleic acid reassociation in the taxonomy of some gram-negative fermentative bacteria. Int. J. Syst. Bacteriol. 24:422-433.

5. Crosa, J. H., D. J. Brenner, and S. Falkow. 1973. Use of a single-strand-specific nuclease for analysis of bacterial and plasmid deoxyribonucleic acid homo- and heteroduplexes. J. Bacteriol. 115:904-911.

6. Davis, M. J., W. J. French, and N. W. Schaad. 1981. Axenic culture of the bacterium associated with phony disease of peach and plum leaf scald. Curr. Microbiol. 6:309-314.

7. Davis, M. J., D. L. Stassi, W. J. French, and S. W. Thompson. 1979. Antigenic relationships of several rickettsia-like bacteria involved in plant diseases, p. 311-315. In Station de Pathologie Vegetale et Phytobacteriologie (ed.), Proceedings of the IVth International Conference on Plant Pathogenic Bacteria. Institut National de la Recherche Agronomique, Angers.

8. Davis, M. J., R. F. Whitcomb, and A. G. Gillaspie, Jr. 1981. Fastidious bacteria of plant vascular tissue and invertebrates (including so-called "rickettsia-like"' bacteria), p. 2172-2188. In M. P. Starr, H. Stolp, H. G. Truper, A. Ballows, and H. G. Schlegel (ed.), The prokaryotes-a handbook of habitats, isolation, and identification of bacteria, vol. 1. Springer-Verlag, Inc., New York.

9. De Ley, J. 1974. Phylogeny of procaryotes. Taxon 23:291-300.

10. De Ley, J., H. Cattoir, and A. Reynaerts. 1970. The quantitative measurement of DNA hybridization from renaturation rates. Eur. J. Biochem. 12:133-142.

11. Felsenfeld, G. 1968. Ultraviolet spectral analysis of nucleic acids. Methods Enzymol. 12B:247-253.

12. French, W. J., D. L. Stassi, and N. W. Schaad. 1978. The use of immunofluorescence for the identification of phony peach bacterium. Phytopathology 68:1106-1108.

13. Gillis, M., J. De Ley, and M. DeCleene. 1970 . The determination of molecular weights of bacterial genome DNA from renaturation rates. Eur. J. Biochem. 12:143-153.

14. Hewitt, W. B., B. R. Houston, N. W. Frazier, and J. H. Freitag. 1946. Leafhopper transmission of the virus causing Pierce's disease of grape and dwarf of alfalfa. Phytopathology 36:117-128.

15. Hopkins, D. L. 1977. Diseases caused by leafhopper-borne rickettsia-like bacteria. Annu. Rev. Phytopathol. 15:277-294.

16. Johnson, J. L. 1973. Use of nucleic-acid homologies in the taxonomy of anaerobic bacteria. Int. J. Syst. Bacteriol. 18:33-47.

17. Marmur, J. 1961. A procedure for the isolation of deoxyribonucleic acid from micro-organisms. J. Mol. Biol. 3:208-218.

18. Marmur, J., and P. Doty. 1962. Determination of the base composition of deoxyribonucleic acid from its thermal denaturation temperature. J. Mol. Biol. 5:109-118.

19. Mircetich, S. M., S. K. Lowe, W. J. Moller, and G. Nyland. 1976. Etiology of almond leaf scorch disease and transmission of the causal agent. Phytopathology 66:17-24.

20. Nome, S. F., B. C. Raju, A. C. Goheen, G. Nyland, and D. Docampo. 1980. Enzyme-linked immunosorbent assay for detection of Pierce's disease bacteria in plant tissues. Phytopathology 70:746-749.

21. Normore, W. M. 1975. Guanine-plus-cytosine composition of the DNA of bacteria, fungi, algae and protozoa, p. 65-235. In G. D. Fasman (ed.), Handbook of biochemistry and molecular biology, 3rd ed. CRC Press, Inc., Cleveland.

22. Raju, B. C., J. M. Wells, G. Nyland, R. H. Brlansky, and S. K. Lowe. 1982. Plum leaf scald: isolation, culture, and pathogenicity of the causal agent. Phytopathology 72:1460-1466.

23. Rigby, P. W. J., M. Dieckmann, C. Rhodes, and P. Berg. 1977. Labeling deoxyribonucleic acid to high specific activity in vitro by nick translation with DNA polymerase I. J. Mol. Biol. 113: 237-251.

24. Wells, J. M., and B. C. Raju. 1984. Cellular fatty acid composition of six fastidious, gram-negative, xylem-limited bacteria. Curr. Microbiol. 10:231-236.

25. Wells, J. M., B. C. Raju, G. Nyland, and S. K. Lowe. 1981. Medium for isolation and growth of bacteria associated with plum leaf scald and phony peach diseases. Appl. Environ. Microbiol. 42:357-363.

26. Wells, J. M., D. J. Weaver, and B. C. Raju. 1980. Distribution of rickettsia-like bacteria in peach, and their occurrence in plum, cherry, and some perennial weeds. Phytopathology 70:817-820. 